\title{
ANATOMI KEKERASAN TERHADAP NOTARIS
}

\author{
Fanny Tanuwijaya \\ Pengajar Fakultas Hukum Universitas Jember \\ J1. Kalimantan No.76, Krajan Timur, Jember \\ email: fannytanuwijaya2018@yahoo.com
}

\begin{abstract}
Abstrak
Kekerasan bisa menimpa siapa saja, tidak terecuali seseorang yang mempunyai pekerjaan atau profesi di bidang hukum seperti Notaris. Ada saja seseorang atau sekelompok orang yang melakukan kekerasan terhadap Notaris. Meskipun demikian, Notaris dalam menjalankan profesinya terikat pada perannya yang memang harus kuat dan berani menghadapi tantangan apapun, termasuk kekerasan guna memberikan layanan yang terbaik pada masyarakat atau pihak-pihak yang membutuhkan dirinya. Kekerasan hanya sebagai bagian kecil dari beragam tantangan yang dihadapinya dalam menjalankan kewenangan, kewajiban, atau tugas-tugas profesionalitasnya.
\end{abstract}

Kata kunci: Notaris, kekerasan, profesionalisme, layanan

\section{Abstract}

Violence can happen to anyone, including someone who has a job or legal profession such as a Notary. There is a person or group of people who commit violence against a Notary. Even so, the Notary in carrying out his profession is bound to his role that indeed must be strong and brave to face any challenges, including violence in order to provide the best service to the society or those who need him. Violence is only a small part of various challenges that has to be faced in carrying out his authority, obligations or professional duties.

Keywords: Notary, violence, professionalism, service

\section{PENDAHULUAN}

Salah satu problem bangsa yang gampang terjadi adalah kekerasan, baik kekerasan individual maupun kekerasan kelompok. Diantara kekerasan yang paling mengkhwatirkan adalah kekerasan yang dilakukan sekelompok orang yang satu terhadap sekelompok orang lainnya, baik atas dasar agama, sosial, etnis, maupun aspek lainnya.

Mengapa kekerasan gampang terjadi di tengah masyarakat? tidakkah masyarakat Indonesia ini mayoritasnya adalah umat atau manusia yang setia pada Pancasila atau ajaran keadaban dan kemanusiaan? Tidakkah manusia Indonesia sudah diajarkan oleh agamanya untuk saling memuliakan 
sesamanya atau menghargai pekerjaan atau profesi yang dilakukan orang atau pihak lain?

Sayangnya tidak sedikit diantara anggota mayarakat atau subyek sosial yang tersesat atau terjerumus melakukan cara-cara atau pola-pola yang tidak beradab atau tidak berperikemanusiaan pada pihak lain. Perbuatan demikan memang kategorinya sebagai tindak kejahatan atau tindak pidana, akan tetapi meski sudah tahu bahwa perbuatan ini adalah melanggar hukum, tetap saja dilakukannya.

Dalam ranah konstitusi, setiap warga negara yanng hidup di Negara Republik Indonesia ini diatur atau dipertanggungjawabka menurut hukum yang berlaku. Hukum dinyatakan berlaku sebagai norma yang mengikat setiap sikap dan perilaku warga negara ini. Mereka dituntut oleh norma hukum untuk menjadi warga yang patuh. Kepatuhannya akan dapat memberikan banyak manfaat baik bagi diri, sesama, masyarakat maupun bangsanya. Hukum berlaku demikian karena mesti ada saja perilaku elemen warga negara yang tidak setia pada hukum, yakni melanggar hukum, contohnya melakukan kekerasan.

Salah satu pihak dari kalangan pengemban profesi hukum yang beberapa kali menjadi korban kekerasan (kejahatan) adalah Notaris. Misalnya ada Notaris yang kepalanya dihantam martil, ada yang diteror, ada yang anak atau anggota keluarganya disakiti, dan berbagai bentuk penganiayaan atau kekerasan jenis lainnya.

Atas berbagai peristiwa kekerasan yang menimpa Notaris itu, wajar jika kita bertanya, mengapa kekerasan sampai menimpa Notaris atau keluarganya?

\section{PEMBAHASAN}

\section{Anatomi Kekerasan}

Menurut Black (1951) kekerasan adalah pemakaian kekuatan yang tidak adil, dan tidak dapat dibenarkan, yang disertai dengan emosi yang hebat atau kemarahan yang tidak terkendali, tiba-tiba, bertenaga, kasar dan menghina. ${ }^{1}$

Menurut Salim dalam Kamus Besar Bahasa Indonesia (1991) istilah "kekerasan" berasal dari kata "keras" yang berarti kuat, padat dan tidak mudah hancur, sedangkan bila diberi imbuhan "ke" maka akan menjadi kata "kekerasan" yang berarti: (1) perihal/sifat keras, (2) paksaan, dan (3) suatu perbuatan yang menimbulkan kerusakan fisik atau non fisik/psikis pada orang lain. ${ }^{2}$ 2014), hal. 23.

${ }^{1}$ Mahmudi, Mewujudkan Impian Indonesia Tanpa Konflik, (Surabaya: Sinar Media

${ }^{2}$ Ibid, hal. 23-24. 
Menurut pasal 1 ayat (1) UU Nomor 23 tahun 2004 tentang Penghapusan Kekerasan Dalam Rumah Tangga, bahwa kekerasan adalah perbuatan terhadap seseorang yang berakibat timbulnya kesengsaraan atau penderitaan secara fisik, psikologis, dan atau penelantaran rumah tangga, termasuk ancaman untuk melakukan perbuatan, pemaksaan, atau perampasan kemerdekaan secara melawan hukum dalam lingkungan rumah tangga. Menurut KUHP pasal 89 disebutkan, kekerasan adalah mempergunakan tenaga atau kekuatan jasmani yang tidak kecil atau sekuat mungkin secara tidak sah sehingga orang yang terkena tindakan itu merasakan sakit yang sangat.

J.E. Sahetapy mempertanyakan atau menggugat mengapa bangsa yang katanya berbudaya, berbudi luhur, ramah, tamah, sopan, santun, religius, tolong menolong, gotong royong, dan lain-lain, berubah menjadi bangsa atau masyarakat yang homo homini lupus, anarkis, brutal, dalam hampir seluruh bidang kehidupan, dan strata. ${ }^{3}$ Pikiran Sahetapy ini sekaligus sebagai gugatan yang bersifat sangat serius terhadap perilaku sebagian orang Indonesia yang tidak beradab atau yang suka menggunakan cara-cara radikalistik atau kriminalistik untuk meyakiti orang lain.

Kekerasan dan eigenrichting (menghakimi sendiri) yang terjadi di mayapada ini, dahulu dan sekarang, meskipun mengandung substansi yang sama, manifestasinya bisa dipelajari sebagai membaca tanda-tanda zaman. Itulah sebabnya amat mudah melihat fenomena kekerasan dari berbagai perspektif serta ramifikasinya dapatlah dideteksi bertalian dengan kemungkinan ada unsur rekayasa atau tidak. ${ }^{4}$ kekerasan demi kekerasan yang terjadi akhirnya menjadi ujian yang mempertanyakan jiwa kebangsaan, keberagamaan, dan keindonesiaan kita, khususnya pada sesama manusia ${ }^{5}$

Dalam sejarah, kekerasan sudah dikenal sejak zaman Habil membunuh Kabil. Menurut Turpin dan Kurtz (1997:2) "understanding human violence is one of the central tasks of our time, yet we still know very little about it, because ...we have neglegted the search for fundamental cause...". 6 Kekerasan adalah suatu tindakan (perbuatan) yang didasari pemaksaaan, kemarahan, kejengkelan, frustrasi, emosi, depresi, dan lainlain, yang disebabkan berbagai alternatif faktor dalam kehidupan, baik

${ }^{3}$ J.E. Sahetapy, Penanggulangan Kekerasan Tanpa Kekerasan, (Jakarta: Komisi Hukum Nasional (KHN), 2002), hal. 15, dan lihat Soehardi dalam Sumjati, Sumjati (Editor), Manusia dan Dinamika Budaya; Dari Kekerasan Sampai Baratayuda, (Yogyakarta: Badan Penelitian dan Publikasi Fakultas (BPPF), Fakultas Sastra UGM \& BIGRAF Publishing, 2001), hal. 3.

${ }^{4}$ J.E. Sahetapy, Kekerasan, untuk Apa?，(Jakarta: The Go-East Institute, 2000), hal 169 dan lihat J.E. Sahetapy,Op.Cit, hal. 14.

${ }^{5}$ Mahmudi, Op. Cit. hal. 3.

${ }^{6}$ J.E. Sahetapy,Op.Cit, hal. 14. 
sosial, ekonomi, psikologis, budaya, dan lain sebagainya. Sehingga adalah tidak mudah menyelesaikan kasus-kasus kekerasan seperti main hakim sendiri (eigenrichting) yang terjadi di Indonesia. Kalau ada upaya penyelesaian maka upaya penyelesaian dimaksud harus melibatkan banyak aspek, banyak pihak, yang harus saling sinergi antara aspek, pihak yang satu dengan aspek, pihak yang lain. ${ }^{7}$

Orang awam umumnya mengartikan kekerasan identik dengan perbuatan aktif membunuh, merusak, membakar, meledakkan, memukul, membacok, memperkosa, menganiaya dan lainnya. Tapi dalam kajian teoritik, dalam berbagai pandangan, kekerasan tidak selalu dimaknai sebagai perbuatan fisik aktif. Ia bisa berupa perbuatan non fisik, yang psikologis, yang theologis, yang kultural, yang sosial, yang ekonomis, yang struktural, bahkan ada yang naratif.. ${ }^{8}$ Thomas Santoso mengelompokkan kekerasan dalam tiga kelompok besar yaitu: (1) kekerasan sebagai tindakan aktor atau kelompok aktor, (2) kekerasan sebagai produk struktur, dan (3) kekerasan sebagai jejaring antara aktor dengan struktur. ${ }^{9}$ Bentuk-bentuk kekerasan lain yang dikenal secara teoritik dalam berbagai literatur yaitu: (1) symbolic violence (Elias,1993), (2) workplace violence (Solomon and King, 1993), (3) structural violence, (4) bureaucratised violence (Turpin and Kurtz, 1997), (5) anarchic violence (Hobbes,1928), (6) juvenile violence, (7) religious violence, dan (8) cultural violence, (9) kekerasan yudisil atau kekerasan legal ${ }^{10}$

Kekerasan secara teoritis mengilustrasikan sifat aturan sosial, pelanggaran aturan, dan reaksi sosial terhadap pelanggaran aturan yang kompleks dan seringkali bertentangan. Perbedaan penting perlu dibuat misalnya antara, kekerasan legal (kekerasan yudisil) dengan kekerasan ilegal. Dalam literatur ilmiah populer sering disebutkan bahwa kekerasan legal (kekerasan yudisil) adalah kekerasan yang dalam ruang, waktu, syarat, prosedur, tata cara, batas-batas, dan tujuan tertentu, menurut hukum diperkenankan atau sudah ada regulasinya. Misalnya orang tua menjewer anaknya, guru menyuruh murid berdiri satu kaki, masing-masing untuk tujuan mendidik. Polisi menangkap, menahan tersangka, polisi menembak penjahat. Jaksa menangkap, menahan tersangka atau terdakwa, hakim menahan terdakwa, hakim mempidana terdakwa, tentara menembak orang

${ }^{7}$ Sumjati, Op.Cit, hal. 8.

${ }^{8}$ Turpin \& Kurtz, 1997:91 dalam Sahetapy, Op.Cit, hal. 14.

${ }^{9}$ Thomas Santoso (Editor), Teori-Teori Kekerasan, (Jakarta: Ghalia Indonesia \& Universitas Kristen Petra, 2002), hal. 10.

${ }^{10} \mathrm{JE}$. Sahetapy, Op.Cit. 
dalam keadaan perang. ${ }^{11}$ Kekerasan legal ini meski tidak diterima oleh pihak yang terkena, tetapi memang inilah yang harus diberlakukan oleh negara. Sedangkan kekerasan yang menimpa orang lain akibat pelanggaran hukum atau sebagai kekerasan non legal merupakan jenis kekerasan yang dapat dikategorikan sebagai kejahatan. ${ }^{12}$

Orang boleh melihat permasalahan kekerasan dari segi budaya (violent culture), mewacanakannya sebagai suatu pesan bersandi (violent as communication), yang bersumber pada substansi diskrepansi kultural, ekonomi, politik, hukum, suku, ras, agama, yang kesemuannya telah lama terpendam sebagai magma ketidak puasan, ketidak adilan, pelanggaran, penindasan, dan sebagainya. Persoalannya ialah siapa yang dapat dijadikan tersangka, terdakwa, terpidana, dan bagaimana negara harus mempertanggungjawabkan segala bentuk kekerasan yang terjadi. ${ }^{13}$

Terjadinya tindak kekerasan di Indonesia relatif ada hubungannya dengan akar budaya bangsa Indonesia. Dahulu antara pelbagai daerah, berbagai kerajaan di nusantara ini, terjadi kekerasan antara daerah (kerajaan) yang satu dengan daerah (kerajaan) yang lain dimana bagi daerah (kerajaan) yang menang, maka kemenangan merupakan simbol kekuasaan, kekuatan, kebanggaan.

The nature of causes konflik horizontal di berbagai kawasan di tanah air kita dapat terbaca seperti dalam kasus Ambon, Sampit, Situbondo, Bali, FPI, dan lain-lainnya, yang akarnya adalah heterogenitas (perbedaan) yang melekat (given) dalam masyarakat itu sendiri. Artinya masyarakat tidak bisa memahami, menginsafi, menyadari, dan mengamalkan bahwa perbedaan yang ada adalah suatu rahmat bagi sesama (perbedaab masih diposisikan sebagai ancaman konstruksi harmonisasi sosial). Kasus Ambon menurut sinyalemen Abdul Syukur adalah berawal dari pergantian pejabat Kristen oleh Gubernur MS Latuconsina, penodongan sopir angkot Kristen oleh Muslim pendatang. ${ }^{14}$

Konflik dalam suatu komunitas (masyarakat) tidak bisa sama sekali dihapuskan atau disterilkan. Adapun yang dapat dilakukan ialah bagaimana mengelola agar konflik dalam suatu komunitas (masyarakat) tidak dilakukan dengan kekerasan, eigenrichting, anarkis, represif. Ralf Dahrendorf menyimpulkan bahwa konflik yang terjadi dalam masyarakat (termasuk hal. 10 .

${ }^{11}$ Jack D. Douglas \& Frances Chaput Waksler dalam Thomas Santoso, Op. Cit.

${ }^{12}$ Dimas Sumitha, Dekonstruksi Akar-akar Kekerasan, (Jakarta: KP-Media Bangsa, 2014), hal. 4.

${ }^{13}$ John Galtung dalam Thomas Santoso, Op.Cit. hal. 183.

${ }^{14}$ Abdul Syukur, Kompas,7/2/2000, dalam Suhartono, Dari Kekerasan ke Kekerasan, (Jakarta: Pustaka Ilmu, 2011), hal. 15. 
Indonesia) adalah karena distribusi kewenangan yang tidak merata, Contoh konflik kewenangan adalah konflik buruh versus majikan, negara versus masyarakat, pemerintah versus oposisi, ${ }^{15}$ atau pengemban profesi hukum dengan kliennya atau siapapun yang tidak merasa suka dan dendam terhadapnya.

Pandangan lain melihat bahwa terjadinya kekerasan, eigenrichting, chaos (kekacauan) sosial atau perilaku berpola kekerasan dalam negara terkait dengan fenomena epidemi moral. Epidemi moral berupa libido destruktif, ambisi penaklukan manusia lain, kecenderungan melecehkan harkat martabat manusia. Epidemi moral muncul akibat menipisnya kesadaran manusia akan bahaya dekadensi moral. Epidemi moral muncul dan berkembang dalam sistem norma moral yang longgar (gampang menoleransi). Konflik sosial dalam arti luas dipicu oleh dua unsur yaitu: (1) pengaruh lingkungan masyarakat (hasutan, adu domba, (2) disporsi batin (kejengkelan, amarah, kebencian). ${ }^{16}$

\section{Notaris Harus Tidak Takut Menghadapi Kekerasan}

Banyak istilah profesi, sehingga banyak pula pakar yang memasukkan unsur suatu aktifitas disebut profesi. Kita tidak hanya mengenal istilah profesi untuk bidang-bidang pekerjaan seperti dokter, guru, militer, pengacara, dan semacamnya, tetapi meluas sampai mencakup bidang seperti manajer, wartawan, pelukis, penyanyi, artis, sekretaris, dan lain sebagainya. Sejalan dengan realitas itu, menurut de George, timbul kebingungan mengenai pengertian profesi itu sendiri sehubungan dengan istilah profesi dan profesional. Kebingungan itu timbul karena banyak orang yang profesional tidak atau belum tentu termasuk dalam pengertian atau kategori profesi. ${ }^{17}$

Pandangan Arief Sidharta ${ }^{18}$ berikut dapat dijadikan perbandingan telaah, bahwa "perkataan profesi dan profesional sudah sering digunakan dan mempunyai beberapa arti. Dalam percakapan sehari-hari, perkataan profesi diartikan sebagai pekerjaan (tetap) untuk memperoleh nafkah (Belanda: baan, Inggeris, job atau occupation), yang legal maupun tidak. Jadi profesi dipahami sebagai setiap pekerjaan untuk memperoleh uang atau hal lainnya yang bisa dinilai dengan uang. Dalam arti yang lebih teknis, profesi dipahami sebagai setiap kegiatan tetap tertentu untuk memperoleh

\footnotetext{
${ }^{15}$ Ralf Dahrendorf, dalam Kris Nugroho dan Thomas Santoso, Episode Tahun Kekerasan 1996 - 1999, (Jakarta: The Go-East Institute, 2000), hal. 66.

${ }^{16}$ William Chang, Kerikil- Kerikil Di Jalan Reformasi; Catatan-Catatan Dari Sudut Etika Sosial, (Jakarta: Kompas, 2002), hal. 109 \&126.

17 Burhanuddin Salam, Etika Sosial, Asas Moral dalam Kehidupan Manusia, (Jakarta: Rineka Cipta, 1997), hal. 137.

${ }^{18}$ B. Arief Sidharta, Etika dan Kode Etik Profesi Hukum, Pro Justitia, Bandung, April 1995, hal. 4
} 
nafkah (penghasilan) yang dilaksanakan secara berkeahlian (khusus) yang berkaitan dengan cara berkarya dan hasil karya yang bermutu tinggi dengan menerima bayaran yang tinggi. Keahlian tersebut diperoleh melalui pengalaman (pekerjaan yang berlangsung terus menerus), belajar pada lembaga pendidikan tinggi tertentu, latihan secara intensif atau kombinasi dari semuanya itu. Dalam kaitan pemahaman ini, sering dibedakan antara profesional dengan profesionalisme sebagai lawan dari amatir dan amatirisme, misalnya dalam dunia olah raga, yang sering juga dikaitkan pada pengertian pekerjaan tetap sebagai lawan dari pekerjaan sambilan.

Thomas Aquinas menyatakan, bahwa setiap wujud kerja mempunyai empat tujuan sebagaimana berikut:

1) Dengan bekerja, orang dapat memenuhi apa yang menjadi kebutuhan hidup sehari-harinya. Bekerja menjadi salah satu cara dalam mencegah keinginan seseorang melakukan perbuatan disnormatifitas yuridis.

2) Dengan adanya lapangan pekerjaan, maka pengangguran dapat dihapuskan/dicegah dari kehidupan masyarakat. Hal ini juga berarti, bahwa dengan tidak adanya pengangguran, maka kemungkinan timbulnya kejahatan (pelanggaran hukum) dapat dihindari pula. Penyakit sosial dapat dicegajh jika seseorang mempunyai aktifitas kerja.

3) Dengan surplus hasil kerjanya, manusia juga dapat berbuat amal bagi sesamanya.

4) Dengan kerja, orang dapat mengontrol atau mengendalikan gaya hidupnya. ${ }^{19}$

Profesi-profesi dalam sistem sosial okupasi (pekerjaan) pada masyarakat modern menempati kedudukan yang sangat strategis, sebagaimana kata Talcott Parson, "the profession occupy a position of importance in our society which is, .... in unique in history, atau dikategorikan pada "it is difficult to imagine how it could get along without basic structural changes if they were seriously impaired. ${ }^{20}$

Pandangan Parson itu menunjukkan tentang posisi istimewa dan pentingnya suatu profesi dalam kehidupan masyarakat. Karena merupakan suatu posisi penting, otomatis tidak setiap pekerjaan dan kegiatan yang bisa dilakukan oleh seseorang disebutnya sebagai suatu profesi. Profesi dalam isyarat Parson itu menuntut kekhususan-kekhususan atau keistimewaankeistimewaan. Jadi tidak setiap orang yang mempunyai pekerjaan atau aktifitas lantas disebutnya sebagai profesi, kecuali pekerjaan ini didasari oleh keistimewaan yang melekat pada pekerjaan itu., sehingga ada

19 E. Sumaryono, Etika Profesi Hukum: Norma-norma Bagi Penegak Hukum, (Yogyakarta: Kanisius, 1997), hal. 25.

20 Bambang Darmawan, Eksaminasi Profesi Hukum . (Surakarta: Legispres, 2011), hal. 16 
pekerjaan yang digolongkan sebagai profesi, namun juga ada pekerjaan sekedar sebagai aktifitas tertentu.

Pengemban profesi merupakan kelompok orang atau seseorang yang membidangi pekerjaan yang khusus melaksanakan kegiatan yang memerlukan ketrampilan dan keahlian tinggi guna memenuhi kebutuhan yang rumit dari manusia, di dalamnya pemakaian dengan cara yang benar akan ketrampilan dan keahlian tinggi, hanya dapat dicapai dengan dimilikinya penguasaan pengetahuan dengan ruang lingkup yang luas, mencakup sifat manusia, kecenderungan sejarah dan lingkungan hidupnya; serta adanya disiplin etika yang dikembangkan dan diterapkan oleh kelompok anggota yang menyandang profesi tersebut.

Salah satu pengemban profesi itu adalah Notaris. Sebagai pengemban profesi mulia, Notaris harus tidak takut menghadapi segala bentk tantangan, termasuk ketika diujia atau dieksaminasi dengan berbagai bentuk kekerasan.

Pandangan Izenic, sebagaimana dikutip oleh Komar Andasasmita dan dikutip kembali oleh Habib Adjie, bentuk atau corak notaris dapat dibagi menjadi dua kelompok utama, yaitu:

1. Notariat Functionnel. Maksudnya wewenang-wewenang pemerintah didelegasikan (gedelegeerd) dan demikian diduga mempunyai kebenaran isinya, mempunyai kekuatan bukti formal, dan mempunyai daya/ kekuatan eksekusi. Di negara-negara yang menganut macam/ bentuk notariat seperti ini terdapat pemisahan yang keras antara "wettelijke" dan "niet wettelijke" werkzaamheden, yaitu pekerjaan-pekerjaan yang berdasarkan undang-undang/ hukum dan yang tidak/ bukan dalam notariat,

2. Notariat Professonal. Dalam kelompok ini walaupun pemerintah mengatur tentang organisasinya, akta-akta notaris itu tidak mempunyai akibat-akibat khusus tentang kebenarannya, kekuatan bukti, demikian pula kekuatan eksekutorialnya. Konsep pengembangan undang-undang dan peraturan kenotariatan di sebuah negara harus mengacu pada konsep besar mazab kenotariatan ini karena masing-masing memiliki landasan filosofi hukum yang berbeda. $^{21}$

Norma yuridis merupakan norma yang secara das sollen sebagai produk lembaga yang berwenang (legislatif), namun akan dinilai kualitasnya ketika sudah masuk dalam ranah das sein (kenyataan atau praktik). ${ }^{22}$ Setiap

${ }^{21}$ Habib Adjie, Meneropong Khazanah Notaris \& PPAT Indonesia (kumpulan tulisan tentang Notaris dan PPAT), (Bandung: Citra ADitya Bakti, 2009), hal. 1-2

${ }^{22}$ Herlambang, Hukum Untuk Rakyat Indonesia, (Jaarta: Pustaka Insani, 2012), hal. 11 
norma yuridis ini terlahir atau terbentuk adalah berkat latar sosial sebagai realitas empiriknya. Produk legislatif merupakan wujud pengakomodasian berbagai bentuk kepentingan riil di masyarakat. Hukum pun demikian, ia disediakan atau dibentuk, diantaranya dijadikan landasan kerja Notaris karena kebutuhan rakyat atau pembangunan yang diselenggarakan oleh negara. Hukum tidak begitu saja hadir tanpa alasan kepentingan atau kebutuhan. ${ }^{23}$ Notaris diberikan norma yuridis pijakan dengan beberapa kali pembaruan merupakan wujud pengakuan negara terhadap urgensi kehadiran Notaris untuk masyarkat atau bangsa ini, sehingga dengan urgensinya yang demikian, logis jika tantangan profesi atau bersifat individu yang dihadapinya tidak ringan. Kerasan yang menimpanya hanya menjadi "sedikt" ujian dalam menjlankan profesinya.

Urgensi Notaris dapat terbaca, bahwa Notaris ditentukan bukan hanya sebagai pihak yang menerapkan atau mengimplementasikan aturan (norma yuridis), tetapi juga harus menjadi investigator yang betul-betul cermat dalam memahami, mempelajari atau menyelidiki dokumen yang dihadapkan padanya. Pekerjaan demikian bisa jadi membawa resiko ketika berdampak munculnya reaksi dari seseorang atau sejumlah orang yang tidak menyukainya.

Pemerintah (negara) mengangkat Notaris sebagai orang-orang yang menjadi "pelayan" masyarakat. Sebagai pihak yang diangkat oleh negara maka Notaris dapat dikategorikan sebagai pejabat negara. Menyandang status atau kedudukan sebagai pejabat negara berarti Notaris menjadi wakil negara, yang berarti harus siap menghadapi apapun demi kebenaran hukum dan keadilan.

Secara yuridis sudah digariskan uregensinya Notaris. Notaris adalah pejabat umum yang berwenang untuk membuat akta autentik dan memiliki kewenangan lainnya sebagaimana dimaksud dalam Undang-Undang ini atau berdasarkan Undang-Undang lainnya (berdasarkan Pasal 1 angkat 1 Undang-Undang Republik Indonesia Nomor 2 Tahun 2014 Tentang Perubahan Atas Undang-Undang Nomor 30 Tahun 2004 Tentang Jabatan Notaris.

Istilah pejabat umum melekat dalam dua produk yuridis itu (Undang-Undang Nomor 2 Tahun 2014 dan Undang-Undang Nomor 30 Tahun 2004 Tentang Jabatan Notaris). Pejabat umum sendiri adalah orang yang menjalankan sebagian fungsi publik dari negara, khususnya di bidang hukum perdata. Pejabat umum adalah seseorang yang diangkat dan diberhentikan oleh pemerintah dan diberi wewenang dan kewajiban untuk melayani publik dalam hal-hal tertentu karena ia ikut serta melaksanakan

${ }^{23}$ Ibid, hal. 3 . 
suatu kekuasaan yang bersumber pada kewibawaan dari pemerintah. Dalam jabatannya tersimpul suatu sifat atau ciri khas yang membedakannya dan jabatan-jabatan lainnya dalam masyarakat Indonesia.

Sebagai pejabat umum, notaris diangkat oleh Menteri untuk melaksanakan sebagian fungsi publik dari negara dan bekerja untuk pelayanan kepentingan umum khususnya dalam bidang hukum perdata, walaupun Notaris bukan merupakan pegawai negeri yang menerima gaji dari negara. Pelayanan kepentingan umum tersebut adalah dalam arti bidang pelayanan pembuatan akta dan tugas-tugas lain yang dibebankan kepada notaris, yang melekat pada predikat sebagai pejabat umum dalam ruang lingkup tugas dan kewenangan notaris.

Soal akta itu, Soegondo Notodisoerjo, menyatakan, bahwa untuk dapat membuat akta otentik, seseorang harus mempunyai kedudukan sebagai "penjabat umum". Di Indonesia, seorang advokat, meskipun ia seorang ahli dalam bidang hukum, tidak berwenang untuk membuat akta otentik, karena ia tidak mempunyai kedudukan sebagai "penjabat umum". Sebaliknya seorang "Pegawai Catatan Sipil" (Ambtenaar van de Burgerlijke Stand) meskipun ia bukan ahli hukum, ia berhak membuat akta-akta autentik untuk hal-hal tertentu, umpamanya untuk membuat akta kelahiran, akta perkawinan, akta kematian. Demikian itu karena ia oleh Undangundang ditetapkan sebagai "pejabat umum" dan diberi wewenang untuk membuat akta-akta itu. ${ }^{24}$ Pembuatan akta-akta demikian sebagia bukti penegasan, bahwa Notaris berurusan dengan aspek vital atau bahkan fundamental dalam kehidupan (kepentingan) masyarakat atau pihak-pihak yang penghadap (pemohon jasa padanya). Akta-akta yang diterbitnya berhubungan dengan jaminan kepastian hukum akan "hak", sehingga bukan tidak mungkin jaminan ini membuat atau mengakibatkan reaksi bermodus kekerasan dari seseorang atau pihak lain yang tidak menyukai peran yang dilakukannya.

Hal itu menunjukkan, bahwa negara mendelegasikan kewenangan atau peran strategis pada Notaris untuk melakukan pencatatan dan penetapan serta penyadaran hukum kepada masyarakat, terutama menyangkut legalitas dokumen perjanjian atau kerja sama. Notaris di negara penganut sistem atau "madzhab" civil law formasi penempatannya diatur oleh pemerintah.

Kalua dibaca atau ditelaah dari kacamata politik hukum pengadan Notaris, maka misalnya pengangkatan Notaris baru akan disesuaikan dengan jumlah yang dibutuhkan untuk mengisi formasi yang kosong. Seorang Notaris dari ranah "mdzhab" civil law akan mengeluarkan akta yang sama

${ }^{24}$ Kartini Soedjendro, Perjanjian Peraihan Hak atas Tanah yang Berpotensi Konflik, (Yogyakarta: Kanisius, 2001), hal. 43. 
persis dengan asli akta (minuta akta) yang disimpan dalam kantor Notaris. Pada salinan akta tersebut yang melakukan tanda tangan cukup Notaris. Tanda tangan itu dilakukan di atas meterai dan dibubuhi stempel resmi Notaris.

Deskripsi kewenangan itu hanya sebagian dari urgensinya kehadiran Notaris di negara ini, yang tidak kalah dengan pengemban profesi hukum lainnya, sehingga kalaupun sampai dihadapkan dengan tantangan dari perilaku orang atau pihak lain yang bermodus kekerasan, yang diantaranya sampai mengakibatkan luka berat atau bahkan meninggal dunia, maka demikian ini menjadi bagian dari resiko profesi yang harus dijalaninya, meski tidak ada yang berharap Notaris menghadapi ujian seperti ini.

\section{KESIMPULAN}

Banyak bentuk atau pola kekerasan yang terjadi di masyarakat, termasuk akar masalahnya. Demikian inilah anatomi kekerasan, yang kekerasan ini bisa menimpa siapa saja, tidak terecuali seseorang yang mempunyai pekerjaan atau profesi di bidang hukum seperti Notaris. Ada saja seseorang atau sekelompok orang yang melakukan kekerasan terhadap Notaris.

Meskipun begitu, Notaris dalam menjalankan profesinya terikat pada perannya yang memang harus kuat dan berani menghadapi tantangan apapun, termasuk kekerasan guna memberikan layanan yang terbaik berdasarkan norma yuridis dan kode etik profesi pada masyarakat atau pihak-pihak yang membutuhkan dirinya. Kekerasan hanya sebagai bagian kecil dari beragam tantangan yang dihadapinya dalam menjalankan kewenangan, kewajiban, atau tugas-tugas profesionalitasnya, sehingga Notaris harus tidak boleh mundur dalam mewujudkan misi mulianya itu.

\section{DAFTAR PUSTAKA}

\section{Buku}

Bambang Darmawan, 2011, Eksaminasi Profesi Hukum . Surakarta: Legispres.

Burhanuddin Salam, 1997, Etika Sosial, Asas Moral dalam Kehidupan Manusia, Jakarta: Rineka Cipta.

Dimas Sumitha, 2014, Dekonstruksi Akar-akar Kekerasan, Jakarta: KPMedia Bangsa.

E. Sumaryono, 1997, Etika Profesi Hukum: Norma-norma Bagi Penegak Hukum, Yogyakarta: Kanisius. 
Habib Adjie, 2009, Meneropong Khazanah Notaris \& PPAT Indonesia (kumpulan tulisan tentang Notaris dan PPAT), Bandung: Citra ADitya Bakti.

Herlambang, 2012, Hukum Untuk Rakyat Indonesia, Jakarta: Pustaka Insani.

J.E. Sahetapy, 2002, Penanggulangan Kekerasan Tanpa Kekerasan, Jakarta: Komisi Hukum Nasional (KHN). , 2000, Kekerasan, untuk Apa?, Jakarta: The Go-East Institute.

Kartini Soedjendro, 2001, Perjanjian Peraihan Hak atas Tanah yang Berpotensi Konflik, Yogyakarta: Kanisius.

Kris Nugroho dan Thomas Santoso, 2000, Episode Tahun Kekerasan 1996 1999, Jakarta: The Go-East Institute.

Mahmudi, 2014, Mewujudkan Impian Indonesia Tanpa Konflik, Surabaya: Sinar Media.

Suhartono, 2011, Dari Kekerasan ke Kekerasan, Jakarta: Pustaka Ilmu.

Sumjati (Editor), Manusia dan Dinamika Budaya; Dari Kekerasan Sampai Baratayuda, (Yogyakarta: Badan Penelitian dan Publikasi Fakultas (BPPF), Fakultas Sastra UGM \& BIGRAF Publishing, 2001), hal. 3.

Thomas Santoso (Editor), 2002, Teori-Teori Kekerasan, Jakarta: Ghalia Indonesia \& Universitas Kristen Petra.

William Chang, 2002, Kerikil- Kerikil Di Jalan Reformasi; CatatanCatatan Dari Sudut Etika Sosial, Jakarta: Kompas.

\section{Jurnal}

B. Arief Sidharta, 1995, Etika dan Kode Etik Profesi Hukum, Pro Justitia, Bandung, April 1995. 